\title{
Peracarid assemblages of Zostera meadows in an estuarine ecosystem (O Grove inlet, NW Iberian Peninsula): spatial distribution and seasonal variation
}

\author{
Patricia Esquete $\cdot$ Juan Moreira $\cdot$ Jesús S. Troncoso
}

Received: 18 June 2010/Revised: 8 October 2010/Accepted: 12 October 2010/Published online: 4 November 2010

(C) Springer-Verlag and AWI 2010

\begin{abstract}
The Galician rias are singular and complex estuarine systems of great economic importance. Seagrasses are key elements of the ecosystem and favor the maintenance of high species diversity in benthic communities. Nevertheless, the ecological role of seagrass meadows in the Galician rias has been only partially assessed. Peracarid crustaceans are an important component of soft-bottom faunas and have great importance for the structure of benthic assemblages. In this work, species diversity, patterns of distribution and seasonal fluctuations of peracarids (Crustacea, Peracarida) are studied in estuarine sediments colonized by two species of Zostera (Z. marina and Z. noltii) at the O Grove inlet (Ría de Arousa, Galicia, NW Iberian Peninsula). The spatial distribution of peracarid assemblages was characterized by high numerical dominances due to a few species, particularly tanaidaceans. The temporal study at a Z. marina meadow showed a strongly seasonal pattern defined by great fluctuations of the amphipod population, the latter being the dominant group in abundance and number of species. The highest numbers of species and individuals were observed in September, with minimum values in March. Analyses pointed out a high correlation among the granulometric features of the studied
\end{abstract}

Communicated by H.-D. Franke.

P. Esquete $(\bowtie) \cdot$ J. S. Troncoso

Departamento de Ecoloxía e Bioloxía Animal,

Universidade de Vigo, Campus de As Lagoas,

36310 Vigo, Spain

e-mail: pesquete@uvigo.es

J. Moreira

Estación de Bioloxía Mariña da Graña,

Universidade de Santiago de Compostela,

Casa do Hórreo Rúa da Ribeira, 1. A Graña,

15590 Ferrol, Spain bottoms and the faunistic attributes. Nevertheless, the presence of the seagrasses should influence in a major way the hydrodynamic and sedimentary features of the habitat and utterly the spatial and temporal patterns observed in the peracarid assemblage in the $\mathrm{O}$ Grove inlet.

Keywords Peracarida $\cdot$ Zostera $\cdot$ Seagrass .

Assemblages · Distribution · Dynamics

\section{Introduction}

The presence of seagrass meadows in estuaries favors the establishment and maintenance of high species diversity in benthic assemblages (Fredette et al. 1990; Montadouin and Sauriau 2000). This is mostly due to their role as ecosystem engineers (Jones et al. 1994; Hasegawa et al. 2008): seagrasses reduce current velocities, and thus influence sedimentation rates. They also constitute a source of organic matter, which positively affects the establishment and survival of many benthic, particularly epifaunal species (Orth et al. 1984; Böstrom et al. 2006; Hasegawa et al. 2008). Furthermore, seagrass meadows represent a nursery habitat for fishes and invertebrates and are therefore crucial for the conservation and restoration of marine environments (Heck et al. 2003).

Peracarids (Crustacea: Peracarida) are one of the dominant taxa in benthic assemblages (Cartes et al. 2001) and are considered good indicators of the environmental conditions (Chintiroglou et al. 2004; Guerra-García and García-Gómez 2004). Besides, peracarids represent an important element of the trophic system (Cartes et al. 2001). Thus, the study of this group is a useful tool to evaluate the health and state of conservation of ecosystems. 
The Galician rias (NW of Spain) are singular, complex and productive estuarine systems, which support activities of great economic importance such as littoral fishing, mussel culture and other kinds of exploitation of sea food resources (Figueiras et al. 2002). In addition, the rias house a variety of hard- and soft-bottom habitats with high numbers of species (Garmendia et al. 1998; Moreira and Troncoso 2007). Because of their social and economic importance, the rias have been the subject of several faunistic studies in the last years (e.g. Junoy and Viéitez 1988; Currás and Mora 1991; Olabarria et al. 1998; Cacabelos et al. 2008; Lourido et al. 2008; Moreira et al. 2008b). However, there is a lack of studies on the fauna inhabiting seagrass meadows along the Galician coast. The ecological role of seagrass meadows in the Galician rias has not yet been properly assessed, despite the importance of seagrasses for the functioning of the ecosystem (Heck and Thoman 1981; Orth et al. 1984; Ersoy Karaçuha et al. 2009).

The $\mathrm{O}$ Grove inlet is of high economic and ecological importance due to mussel culture and tourism, on the one hand, and the presence of the extensive seagrass meadows, on the other hand. In fact, Zostera marina $\mathrm{L}$. and Z. noltii Hornem. meadows cover the major part of the intertidal and shallow subtidal sediments of the inlet; this contributes to habitat complexity and thus to high values of benthic biodiversity (Quintas 2005).

As a starting point for a better understanding of the role of Zostera meadows in the ecosystem of the Galician rias, we (1) characterized the peracarid assemblage present in the Zostera spp. beds of the O Grove inlet and (2) studied possible seasonal changes of this assemblage in a representative Zostera marina bed.

\section{Materials and methods}

Study area and sampling procedures

The Ensenada de O Grove is located in the southern part of the Ria de Arousa (Galicia, NW Iberian Peninsula), between $42^{\circ} 41^{\prime}-42^{\circ} 28^{\prime} \mathrm{N}$ and $9^{\circ} 01^{\prime}-8^{\circ} 44^{\prime} \mathrm{W}$ (Fig. 1). It is a sheltered inlet, influenced by high precipitations in autumn/ winter and affected seasonally by freshwater input from several streams. The peracarid fauna inhabiting the Zostera meadows at $\mathrm{O}$ Grove was studied at both spatial and temporal scales. The spatial study was done in December 1996 and comprised 10 sampling sites to assure a representative coverage of the seagrass meadows, which are composed of Z. marina, Z. noltii or both of them (Fig. 1). For the temporal study, samples were taken bimonthly between May 1998 and March 1999 in site D27, a subtidal area colonized by Z. marina, which was assumed to be less affected by salinity fluctuations than meadows located in
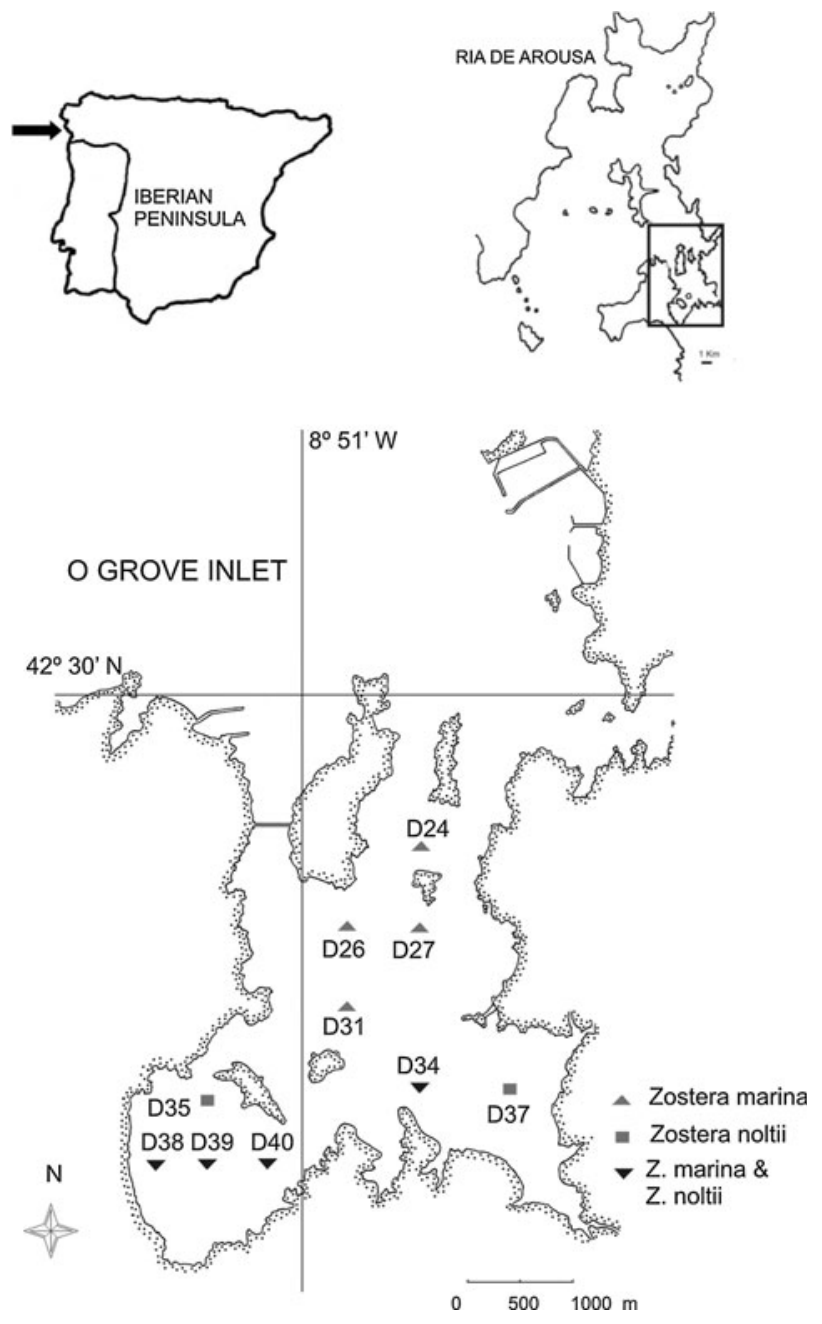

Fig. 1 Location of the O Grove inlet and sampling sites

the innermost parts of the inlet. This site was furthermore selected because of its high peracarid diversity and the good state of conservation of the meadow.

The spatial study was part of a larger project on the benthic environment of the Ria de Arousa. In order to unify the sampling procedure across different kinds of soft substrata, samples were taken by means of a Van Veen grab. Usually, studies on benthic faunas of seagrass meadows are performed by collecting samples with corers or quadrats (e.g. Blanchet et al. 2004; Fredriksen et al. 2005; González et al. 2008). Nevertheless, the grab used here was considered to take representative samples of the bottom; anyway, samples were discarded when the grab closed on Zostera roots and a substantial part of the sample could have been lost. Five replicate samples were taken at each site, thus covering a total area of $0.28 \mathrm{~m}^{2}$ per site. Samples were sieved through a $0.5-\mathrm{mm}$ mesh and fixed in $10 \%$ buffered formalin for later sorting and identification of the fauna. An additional sample was taken at each site for granulometric analyses and to determine calcium carbonate and organic 
matter content. Also, a sample of the bottom water was taken by means of a Niskin bottle. The following granulometric fractions were distinguished: gravel ( $>2 \mathrm{~mm})$, very coarse sand (1-2 mm), coarse sand $(0.5-1.0 \mathrm{~mm})$, medium sand $(0.25-0.50 \mathrm{~mm})$, fine sand $(0.125-0.250 \mathrm{~mm})$, very fine sand $(0.063-0.125 \mathrm{~mm})$ and silt/clay $(<0.063 \mathrm{~mm})$. Median grain size $\left(\mathrm{Q}_{50}\right)$ and the sorting coefficient $\left(\mathrm{S}_{0}\right)$ were also determined for each site. Calcium carbonate content (\%) was estimated by treating the sample with hydrochloric acid in a Bernard Calcimeter, and the total organic matter content (TOM, \%) was estimated from the weight loss of samples dried in a furnace for $4 \mathrm{~h}$ at $450^{\circ} \mathrm{C}$. Temperature and $\mathrm{pH}$ of bottom seawater were measured in situ, by means of a portable microprocessor model HI9025C (Hanna instruments). Salinity was measured by means of a refractometer model S/Mill-E (Atago).

For the study of possible seasonal changes in the fauna, samples were taken at site D27 in May, July, September and November 1998, as well as in January and March 1999 by Scuba divers. At each sampling date, the seagrass cover of five replicate quadrats of $0.0625 \mathrm{~m}^{2}$ each was harvested; the shoot and rhizome fractions (the latter including the sediment) were kept separately in plastic bags. An additional sample of sediment was taken for granulometric analyses and to determine calcium carbonate and organic matter content. Salinity, $\mathrm{pH}$ and temperature were measured in situ. Samples destined for faunal analysis were sieved through a $0.5-\mathrm{mm}$ mesh and fixed in $10 \%$ buffered formalin.

\section{Data analyses}

Univariate measures were calculated for each sampling site and date: total abundance $(N)$, number of species $(S)$, Shannon-Wiener's diversity index $\left(H^{\prime}\right.$, as $\left.\log _{2}\right)$ and Pielou's evenness $\left(J^{\prime}\right)$. Peracarid assemblages (spatial study) and patterns of seasonal changes (site D27) were determined through non-parametric multivariate techniques as described by Clarke and Warwick (1994), using PRIMER 6 (Plymouth Routines in Multivariate Ecological Research) software package. The Bray-Curtis similarity index was applied on the fourth-root transformed data (to downweight the contribution of the most abundant species). Data were previously averaged through the five replicates for each site/date thus obtaining a centroid. Classification of sampling sites/dates was done by cluster analysis based on the group-average sorting algorithm and tested by Simprof test. Non-metric multidimensional scaling (nMDS) was used to produce a visual representation of the ordination of centroids. The SIMPER analysis served to identify the species that contributed most to the differentiation of the groups of samples (sampling sites/dates). The possible relationship between the peracarid assemblages and the measured environmental variables was analyzed by the BIO-ENV procedure. All variables expressed in percentages were previously transformed by $\log (x+1)$.

\section{Results}

Spatial distribution

\section{Environmental variables}

Sediments were composed mainly of muddy sand, with relatively high percentages of fine and very fine sand (up to 64.6 and $47.9 \%$, respectively) and silt/clay (up to $61.6 \%$ in site D37). Salinity was relatively low (maximum 33\%o) especially for sites 34 and 37 (around 20\%o). Content in TOM was high (up to $15.55 \%$ ), whereas content in calcium carbonate was low $(<10.5 \%)$. Values of the studied variables are detailed for each site in Table 1.

\section{Fauna}

A total of 15,523 individuals belonging to 113 species were identified (those with $>1 \%$ of dominance are detailed in Table 2). Tanaids accounted for $52 \%$ of the specimens, with Apseudes latreillii (Milne-Edwards, 1828) being the numerically dominant species (40.2\%). Amphipods were the group best represented in number of species (83) and constituted $35.8 \%$ of the specimens. The least represented group was cumaceans, which accounted for only $3.12 \%$ of the total abundance.

The highest number of species was found in site D27 (60); diversity $\left(H^{\prime}\right)$ and evenness $\left(J^{\prime}\right)$ indexes were low for this site $\left(H^{\prime}: 2.05 ; J^{\prime}: 0.51\right)$. Both $H^{\prime}$ and $J^{\prime}$ were highest for sites D38, D39 and D40 $\left(H^{\prime}: 3.74-4.07 ; J^{\prime}: 0.73-0.78\right)$.

The ANOSIM test showed significant differences in faunistic composition among sites (global $R$ : 0.823 , $P<0.001)$. The cluster dendrogram and the graphic representation of the nMDS analysis revealed the existence of three major groups of sites (Fig. 2). Group A (similarity level of $60 \%$ ) comprised four sites located in the central part of the inlet and colonized by Z. marina (D24, D26, D27 and D31). The species that mostly contributed to the similarity were the tanaids, Apseudes latreillii and Zeuxo holdichi Bamber, 1990, followed by the caprellids, Caprella acanthifera Leach, 1814 and Pariambus typicus (Krøyer, 1884). Group B was composed of two sites colonized by both species of seagrasses, situated in the sheltered south-western part of the inlet (D38 and D39; similarity of 70\%). Uromunna spp., Microdeutopus spp., Gammarella fucicola (Leach, 1814) and Apseudes talpa (Montagu, 1808) were the taxa determining this group. Site D35 was also included in this group (similarity of $60 \%$ ), 
Table 1 Spatial study: environmental variables measured in different sites

\begin{tabular}{|c|c|c|c|c|c|c|c|c|c|c|}
\hline & D24 & D26 & D27 & D31 & D34 & D35 & D37 & D38 & D39 & $\mathrm{D} 40$ \\
\hline T sed. $\left({ }^{\circ} \mathrm{C}\right)$ & 12.50 & 11.10 & 11.60 & 13.40 & 12.70 & 13.50 & 12.90 & 12.60 & 12.70 & 12.80 \\
\hline $\mathrm{T}$ bottom water $\left({ }^{\circ} \mathrm{C}\right)$ & 14.60 & 10.00 & 9.90 & 16.70 & 13.00 & 15.30 & 13.20 & 13.20 & 13.00 & 13.30 \\
\hline pH sed. & 7.36 & 7.53 & 7.41 & 7.39 & 7.27 & 7.46 & 7.20 & 7.30 & 7.29 & 7.26 \\
\hline $\mathrm{pH}$ bottom water & 7.76 & 7.90 & 7.85 & 7.81 & 7.74 & 7.89 & 7.74 & 7.71 & 7.70 & 7.73 \\
\hline Salinity (\%o) & 29.00 & 30.00 & 32.00 & 32.50 & 30.00 & 30.50 & 20.00 & 33.00 & 33.00 & 32.00 \\
\hline Gravel & 1.87 & 4.44 & 0.38 & 1.95 & 0.23 & 0.68 & 1.03 & 5.77 & 1.05 & 22.38 \\
\hline Very coarse sand & 0.50 & 2.38 & 0.21 & 0.57 & 0.14 & 0.53 & 0.36 & 1.09 & 0.37 & 3.95 \\
\hline Coarse sand & 0.97 & 4.56 & 0.45 & 0.91 & 1.83 & 1.54 & 1.86 & 2.81 & 1.00 & 5.00 \\
\hline Medium sand & 3.82 & 10.19 & 2.37 & 4.76 & 10.97 & 14.48 & 3.88 & 5.13 & 4.72 & 9.71 \\
\hline Fine sand & 40.14 & 46.14 & 37.80 & 58.03 & 20.85 & 64.63 & 11.77 & 18.51 & 43.58 & 18.36 \\
\hline Very fine sand & 40.68 & 25.89 & 47.89 & 23.20 & 33.93 & 11.40 & 19.49 & 29.66 & 31.07 & 13.17 \\
\hline Silt/clay & 12.01 & 6.41 & 10.90 & 10.59 & 32.05 & 6.75 & 61.61 & 37.02 & 18.22 & 27.44 \\
\hline $\mathrm{Q}_{50}$ & 0.12 & 0.17 & 0.11 & 0.16 & 0.18 & 0.19 & 0.10 & 0.11 & 0.13 & 0.18 \\
\hline $\mathrm{S}_{0}$ & 1.52 & 1.50 & 1.48 & 1.45 & 1.82 & 1.30 & 2.31 & 1.70 & 1.61 & 1.99 \\
\hline TOM (\%) & 3.93 & 1.37 & 2.98 & 2.80 & 5.08 & 1.32 & 15.55 & 10.75 & 3.32 & 7.10 \\
\hline Carbonate content $(\%)$ & 7.58 & 10.05 & 8.46 & 8.69 & 7.22 & 10.46 & 5.41 & 7.40 & 9.59 & 7.17 \\
\hline
\end{tabular}

Granulometric fractions in \%, T sed temperature of the sediment, $T$ bottom water temperature of the bottom water, $p H$ sed $\mathrm{pH}$ of the sediment, $p H$ bottom $\mathrm{pH}$ of the bottom water, $Q_{50}$ median grain size, $S_{0}$ sorting coefficient, TOM total organic matter

although this was not supported by the Simprof test. Group C (similarity 50\%) was formed by two sites located near the mouth of rivers in the south-east (D34, with both Z. marina and noltii; D37, only with $Z$. noltii) and another site hosting both seagrasses (D40); the latter was situated on the other side of the inlet, near site D39. The species that most contributed to the similarity of this group were the isopods, Idotea chelipes (Pallas, 1766) and Idotea balthica (Pallas, 1772), followed by the amphipods, Corophium sextonae Crawford, 1937 and C. insidiosum Crawford, 1937.

The BIO-ENV procedure revealed that the combination of salinity, gravel, fine sand and silt/clay had the highest correlation with the faunal composition, according to the values of the Spearman's rank correlation coefficient $\left(\rho_{w}\right.$ : $0.734)$. The variable that showed the best correlation was silt/clay $\left(\rho_{w}: 0.603\right)$.

\section{Seasonal changes}

\section{Environmental variables}

The temperature of the bottom water reached a minimum in March $\left(12.4^{\circ} \mathrm{C}\right)$ and a maximum in July $\left(25.2^{\circ} \mathrm{C}\right)$. Fine and very fine sand were the dominant granulometric fractions throughout the year at site D27 (20.9-58.0\% and 11.4-40.7\%, respectively). Coarser granulometric fractions were present in small percentages, showing some variation over the study period. Silt/clay fraction showed more or less constant values, reaching the maximal content in January $(32.1 \%)$. Calcium carbonate and organic matter contents showed slight variations over the year, with maximal values in March (TOM, 4.6\%; calcium carbonate, $9.9 \%$ ). Details are shown in Table 3.

\section{Fauna}

A total of 5,768 individuals belonging to 83 species were found in the study period. Amphipods were dominant in number of the specimens (69.4\% of total abundance), followed by tanaids $(21.8 \%)$, isopods $(8 \%)$ and cumaceans $(0.8 \%)$. Amphipods were also numerically dominant at each sampling date except for July, when tanaidaceans were the dominant group (Fig. 3). The dominant species was the amphipod, Gammarella fucicola (23.6\% of total abundance), followed by the tanaid, Zeuxo holdichi (18.6\%), and the caprellid, Phtisica marina Slabber, 1769 (16.6\%; Fig. 4).

The highest numbers of species and individuals were observed in September, minimal numbers in March. Diversity $\left(H^{\prime}\right)$ and evenness $\left(J^{\prime}\right)$ were minimal in summerautumn, reaching the highest values in January (Table 4).

The ANOSIM test showed significant differences in faunistic composition among all sampling dates (global $R$ : $0.634, P<0.001)$. Cluster analysis and nMDS ordination showed two defined groups of samples (Fig. 5): springsummer (May and July; group A) and autumn-winter (November, January and March; group B). The September 
Table 2 Spatial study: list of the peracarid orders and most abundant species ( $>1 \%$ dominance) with abundances (individuals $\left./ 0.28 \mathrm{~m}^{2}\right)$ in the different sampling sites, total abundances and dominance $(\%)$

\begin{tabular}{|c|c|c|c|c|c|c|c|c|c|c|c|c|}
\hline & D24 & D26 & D27 & D31 & D34 & D35 & D37 & D38 & D39 & D40 & Total & $D(\%)$ \\
\hline AMPHIPODA (total) & 437 & 510 & 1,064 & 267 & 858 & 126 & 68 & 1,116 & 671 & 444 & 5,561 & 35.82 \\
\hline Stenothoe monoculoides (Montagu, 1815) & 21 & 9 & 6 & 3 & 23 & 3 & 0 & 10 & 4 & 87 & 166 & 1.07 \\
\hline Gammarus tigrinus Sexton, 1939 & 0 & 1 & 1 & 0 & 213 & 0 & 1 & 10 & 0 & 1 & 227 & 1.46 \\
\hline Gammarella fucicola (Leach, 1814) & 17 & 22 & 516 & 18 & 0 & 1 & 2 & 170 & 69 & 5 & 820 & 5.28 \\
\hline Melita palmata (Montagu, 1804) & 0 & 0 & 1 & 0 & 0 & 6 & 6 & 0 & 0 & 157 & 170 & 1.09 \\
\hline Perioculodes aequimanus (Kossmann, 1880) & 28 & 5 & 7 & 8 & 1 & 11 & 0 & 55 & 105 & 68 & 288 & 1.85 \\
\hline Harpinia pectinata Sars, 1891 & 12 & 55 & 78 & 16 & 0 & 11 & 0 & 33 & 39 & 0 & 244 & 1.57 \\
\hline Dexamine spinosa (Montagu, 1813) & 25 & 5 & 28 & 12 & 0 & 0 & 0 & 74 & 34 & 0 & 178 & 1.15 \\
\hline Aoridae indet. & 0 & 1 & 0 & 1 & 12 & 0 & 0 & 246 & 16 & 4 & 280 & 1.80 \\
\hline Microdeutopus spp. & 13 & 9 & 17 & 30 & 60 & 6 & 3 & 166 & 81 & 27 & 412 & 2.65 \\
\hline Microdeutopus versiculatus (Bate, 1856) & 2 & 64 & 1 & 0 & 96 & 0 & 1 & 0 & 1 & 0 & 165 & 1.06 \\
\hline Siphonoecetes sabatieri de Rouville, 1894 & 0 & 0 & 0 & 0 & 0 & 7 & 0 & 0 & 149 & 0 & 156 & 1.00 \\
\hline Pariambus typicus (Krøyer, 1804) & 22 & 17 & 178 & 25 & 0 & 0 & 0 & 0 & 1 & 0 & 243 & 1.56 \\
\hline ISOPODA (total) & 14 & 76 & 100 & 60 & 55 & 26 & 449 & 199 & 94 & 194 & 1,267 & 8.16 \\
\hline Cyathura carinata (Krøyer, 1847) & 0 & 74 & 2 & 0 & 1 & 6 & 3 & 15 & 6 & 68 & 175 & 1.13 \\
\hline Uromunna spp. & 12 & 0 & 10 & 57 & 2 & 16 & 0 & 180 & 87 & 4 & 368 & 2.37 \\
\hline CUMACEA (total) & 196 & 10 & 96 & 26 & 0 & 26 & 0 & 58 & 70 & 3 & 485 & 3.12 \\
\hline Iphinoe trispinosa (Goodsir, 1843) & 173 & 2 & 30 & 8 & 0 & 5 & 0 & 9 & 10 & 3 & 240 & 1.55 \\
\hline TANAIDACEA (total) & 1,456 & 1,411 & 2,711 & 1,424 & 0 & 258 & 0 & 662 & 248 & 30 & 8,200 & 52.82 \\
\hline Apseudes latreillii (Milne- Edwards, 1828) & 1,394 & 806 & 2,699 & 1,250 & 0 & 37 & 0 & 30 & 24 & 0 & 6,240 & 40.20 \\
\hline Apseudes talpa (Montagu, 1808) & 0 & 530 & 0 & 0 & 0 & 15 & 0 & 61 & 117 & 3 & 726 & 4.68 \\
\hline Leptochelia savignyi (Kroyer, 1842) & 0 & 0 & 0 & 1 & 0 & 12 & 0 & 400 & 51 & 1 & 465 & 2.99 \\
\hline Zeuxo holdichi Bamber, 1990 & 59 & 70 & 6 & 173 & 0 & 194 & 0 & 171 & 23 & 4 & 700 & 4.51 \\
\hline Pielou's evenness $\left(\mathbf{J}^{\prime}\right)$ & 0.42 & 0.54 & 0.35 & 0.38 & 0.72 & 0.67 & 0.68 & 0.74 & 0.79 & 0.74 & & \\
\hline Shannon-Wiener's diversity index $\left(\mathrm{H}^{\prime}\right)$ & 2.39 & 3.07 & 2.05 & 2.04 & 3.72 & 3.62 & 2.94 & 4.07 & 4.48 & 3.74 & & \\
\hline
\end{tabular}

sampling appeared separated from both groups. Group A (70\% similarity) was defined by Zeuxo holdichi, Stenothoe monoculoides (Montagu 1815), Uromunna spp. and Microdeutopus spp. Group B (60\% similarity) was characterized by Z. holdichi, S. monoculoides and Gammarella fucicola. In the x-axis, the September sampling appeared to be closest to group A (70\% similarity), but this was not supported by the Simprof test.

The BIO-ENV procedure revealed that the combination of $\mathrm{pH}$, temperature of bottom water and content in medium sand, very fine sand and silt/clay had the highest correlation with peracarid fauna, according to the Spearman's rank correlation coefficient $\left(\rho_{w}: 0.532\right)$.

\section{Discussion}

The Zostera meadows at the $\mathrm{O}$ Grove inlet have a very diverse peracarid fauna, with a total of 113 taxa identified in this study. The assemblages were numerically dominated by tanaidaceans (53\% of the total abundance) and amphipods $(36 \%)$; on the other hand, amphipods were the peracarid order with the highest number of species (85). The high numerical dominance of tanaidaceans was mostly due to Apseudes latreillii, particularly in sites colonized by Zostera marina.

The species composition of the studied seagrass meadows was typical for north-east Atlantic estuarine sediments (Cunha et al. 1999; Dauvin et al. 2009). However, in other similar estuarine environments of the North Atlantic and the Mediterranean, whether colonized by seagrasses, the number or peracarid species was often smaller and tanaidaceans were very scarce or even absent (Cunha et al. 1999; Cartes et al. 2007; Dauvin et al. 2009). In seagrass meadows, the total number of species was usually high, although tanaidacean densities were much lower than in the present study (Gambi et al. 1992; Sfriso et al. 2001; Paganelli et al. 2005; Ersoy Karaçuha et al. 2009). In general, amphipods were dominant in most of the studies listed above. This dominance may be explained by the fact 


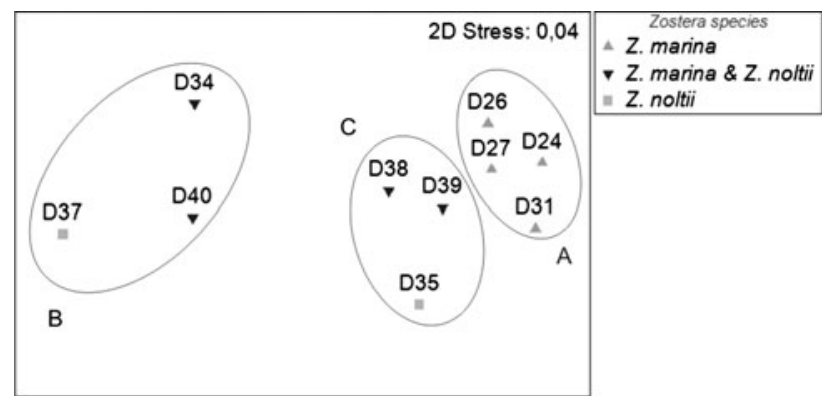

Fig. 2 nMDS ordination of sampling sites showing the groups determined by cluster analysis. The Zostera species present in each site are also indicated

that amphipods are highly diversified both taxonomically and in terms of niche occupation (habitat preferences, feeding habits) and life strategies (e.g. Lancellotti and Trucco 1993; Nelson et al. 1982). Seagrass meadows in turn provide a variety of microhabitats and food sources (vegetal biomass, detritic deposits, epiphytes on seagrasses) to be colonized and exploited by amphipods.

High densities of the tanaid, Apseudes latreilli, have recently been reported in several studies and have often been linked to organic and/or inorganic pollution (Cruz et al. 2003; Guerra-García and García-Gómez 2004; Tomasetti et al. 2009). According to Riggio (1996), A. latreilli is found frequently in sediments with detritic deposits. In the $\mathrm{O}$ Grove inlet, organic matter contents are high in general, and extensive mussel culture also contributes to a significant detritus input. These features, together with the pollution related to intense vessel activities, may have favored the establishment of large populations of A. latreillii in the inlet.

Recent benthic studies of several Galician rias have pointed out a particular richness in peracarid species when compared to similar environments of the North Atlantic (Lourido et al. 2008; Moreira et al. 2008a, b). The granulometric characteristics of the sediment have been suggested the main factor in structuring those assemblages. Nevertheless, in the study area, the presence of the seagrasses undoubtedly contributes to the establishment and structure of the peracarid assemblage by providing, for example, an increased habitat complexity. Furthermore, seagrasses enhance sedimentation rates and organic matter supply and are crucial for the sedimentary features of the habitat (Böstrom et al. 2006; Hasegawa et al. 2008). As expected, the organic matter contents measured in the Zostera meadows at the $\mathrm{O}$ Grove inlet was high, and multivariate analysis indicated that peracarid assemblages were positively correlated with the granulometric composition, especially with the silt/clay fraction. This granulometric fraction is easily suspended and drifted away by hydrodynamism in spite of the presence of the seagrasses (Hasegawa et al. 2008), and then distributed irregularly across the meadows. This provides the basis for restricted distributions of infaunal species in the meadows depending on species-specific differences in granulometric preferences. Indeed, we observed that infaunal species such as

Table 3 Seasonal study: environmental variables measured in site D27 at different dates

\begin{tabular}{|c|c|c|c|c|c|c|}
\hline & May & July & September & November & January & March \\
\hline $\mathrm{T}$ sed. $\left({ }^{\circ} \mathrm{C}\right)$ & 19.30 & 18.80 & 19.60 & 16.90 & 21.20 & 12.30 \\
\hline $\mathrm{T}$ bottom water $\left({ }^{\circ} \mathrm{C}\right)$ & 21.50 & 25.20 & 20.10 & 17.20 & 21.20 & 12.40 \\
\hline pH sed. & 7.25 & 7.28 & 7.19 & 7.45 & 7.56 & 6.38 \\
\hline $\mathrm{pH}$ bottom water & 8.05 & 7.79 & 7.66 & 7.73 & 7.55 & 7.58 \\
\hline Salinity (\%o) & 32.00 & 34.70 & 40.40 & 40.80 & 32.70 & 41.00 \\
\hline Gravel & 1.9 & 4.4 & 0.4 & 1.9 & 0.2 & 0.7 \\
\hline Very coarse sand & 0.5 & 2.4 & 0.2 & 0.6 & 0.1 & 0.5 \\
\hline Coarse sand & 1.0 & 4.6 & 0.4 & 0.9 & 1.8 & 1.5 \\
\hline Medium sand & 3.8 & 10.2 & 2.4 & 4.8 & 11.0 & 14.5 \\
\hline Fine sand & 40.1 & 46.1 & 37.8 & 58.0 & 20.9 & 64.6 \\
\hline Very fine sand & 40.7 & 25.9 & 47.9 & 23.2 & 33.9 & 11.4 \\
\hline Silt/clay & 12.0 & 6.4 & 10.9 & 10.6 & 32.1 & 6.7 \\
\hline $\mathrm{Q}_{50}$ & 3.050 & 2.950 & 2.183 & 2.283 & 1.283 & 4.600 \\
\hline $\mathrm{S}_{0}$ & 8.089 & 8.506 & 8.406 & 8.183 & 8.511 & 9.930 \\
\hline TOM $(\%)$ & 0.1932 & 0.1745 & 0.1963 & 0.1725 & 0.2505 & 0.1747 \\
\hline Carbonate content $(\%)$ & 1.339 & 1.470 & 1.345 & 1.689 & 1.567 & 1.597 \\
\hline
\end{tabular}

Granulometric fractions in \%, T sed temperature of the sediment, $T$ bottom water temperature of the bottom water, $p H$ sed $\mathrm{pH}$ of the sediment, $p H$ bottom $\mathrm{pH}$ of the bottom water, $Q_{50}$ median grain size, $S_{0}$ sorting coefficient, TOM total organic matter 


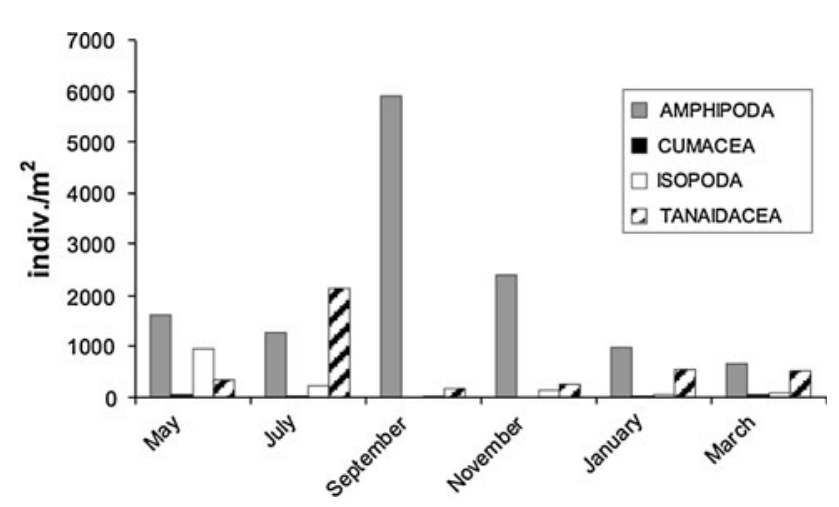

Fig. 3 Total abundance (individuals per $\mathrm{m}^{2}$ ) of the four peracarid orders per sampling date at site D27

Pariambus typicus and A. latreillii, which have been related with the silt/clay fractions (Guerra-García et al. 2003), contributed significantly to the characterization of the assemblages.

Peracarid assemblages of the Zostera marina meadows in the center of the inlet constituted a definite group (A) in the cluster analysis. The assemblages corresponding to the other two groups (B and C) were found in meadows composed of Z. noltii or a mixture of both species. Group C (sites D35 and D37) is clearly defined in the nMDS ordination and is located close to the mouth of several rivers. The differences in those peracarid assemblages might be related to the different conditions in salinity observed across the inlet. In wet climates, macrofaunal distributions in estuaries are influenced by salinity gradients (Talley et al. 2000). Indeed, salinity affects peracarids in estuarine areas more than any other environmental factor (Paganelli et al. 2005). In fact, in the sites of group $C$, euryhaline species such as Idotea balthica, I. chelipes, Corophium acherusicum Costa, 1851, C. insidiosum, Gammarus tigrinus Sexton, 1939, and G. insensibilis Stock, 1966, were more abundant than in the sites of the other two groups, while species less tolerant to changes in salinity (i.e. tanaidaceans) were completely absent. In conclusion, our results suggest that the spatial variations in peracarid assemblages found at the O Grove inlet are related to three main factors: sediment characteristics, seagrass species composition and salinity conditions.

In the second part of the study (seasonal changes in the peracarid assemblage of a subtidal Z. marina meadow; D27), the numbers of species and total numbers of individuals were generally lower than in the samples (including those from D27) taken for the first (spatial) part of the study. This might be due to the different sampling techniques, as scuba diving (used in the seasonal study) might expose peracarids to a higher rate of disturbance than a Van Veen grab (applied in the spatial study). Indeed, some peracarid taxa tend to escape or bury into the sediment when disturbed; for example, Guerra-García and GarcíaGómez (2008) observed that tanaidaceans are able to bury actively to deeper levels when disturbed by a sampling device. That would explain in particular the low abundances of Apseudes latreillii compared to those found for the same site in the spatial scale study.

The studied peracarid assemblage showed clear seasonal changes. There was a decline in the total abundances and numbers of species from autumn through winter for all orders of peracarids, while diversity and evenness indexes increased. This seasonality in peracarid assemblages is typical of temperate latitudes (Cunha et al. 1999; Moreira et al. 2008a; Ersoy Karaçuha et al. 2009). The reasons may be diverse: Frequent rains characterize winter and autumn periods at the area of study, altering the salinity conditions in estuarine habitats, and thus leading to changes in the benthic assemblages (Szedlmayer and Able 1996; Cunha et al. 1999). Furthermore, life histories with seasonal changes in reproductive activity and dispersal may explain variations of the benthic crustacean assemblages over the annual cycle (Cunha et al. 1999; Moreira et al. 2008a).
Fig. 4 Total abundance (individuals per $\mathrm{m}^{2}$ ) of Phtisica marina, Gammarella fucicola, Uromunna spp. and Zeuxo holdichi per sampling date at site D27
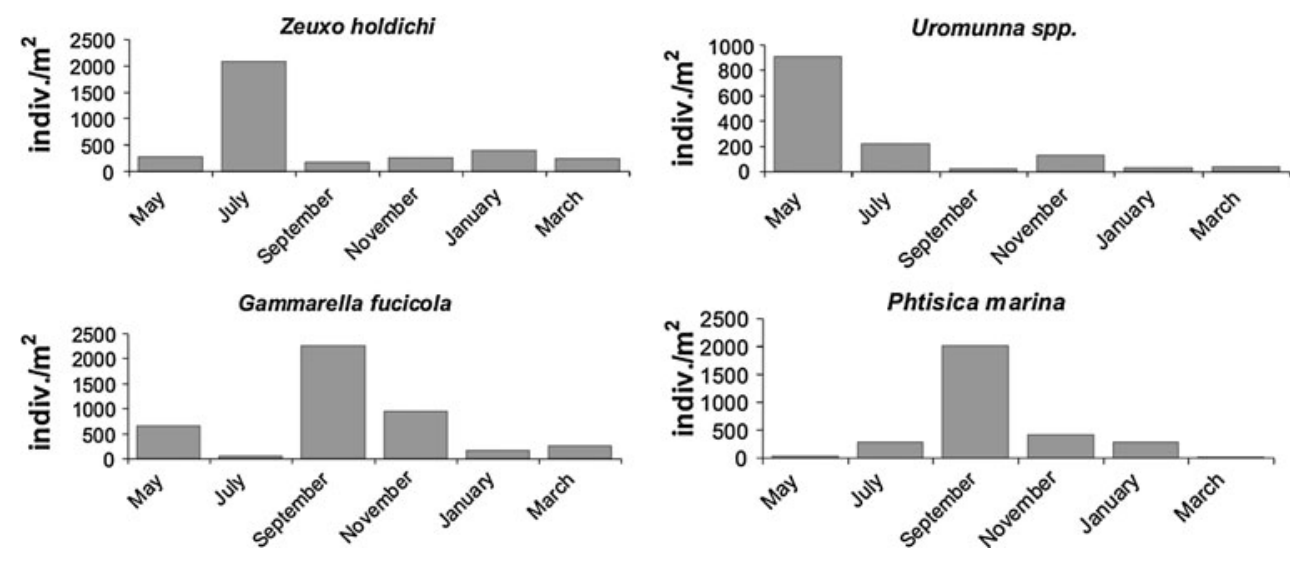
Table 4 Faunistic parameters for each sampling date at site D27

\begin{tabular}{llrll}
\hline & $S$ & $N$ & $J^{\prime}$ & $H^{\prime}$ \\
\hline May & 40 & 925 & 0.64 & 3.39 \\
July & 33 & 1,146 & 0.52 & 2.63 \\
September & 42 & 1,911 & 0.52 & 2.82 \\
November & 38 & 876 & 0.64 & 3.36 \\
January & 35 & 499 & 0.70 & 3.59 \\
March & 33 & 411 & 0.68 & 3.41 \\
\hline
\end{tabular}

$S$ number of species; $N$ total number of individuals (individuals/ $\left.0.31 \mathrm{~m}^{2}\right) ; H^{\prime}$ Shannon-Wiener's diversity index; $J^{\prime}$ Pielou's evenness

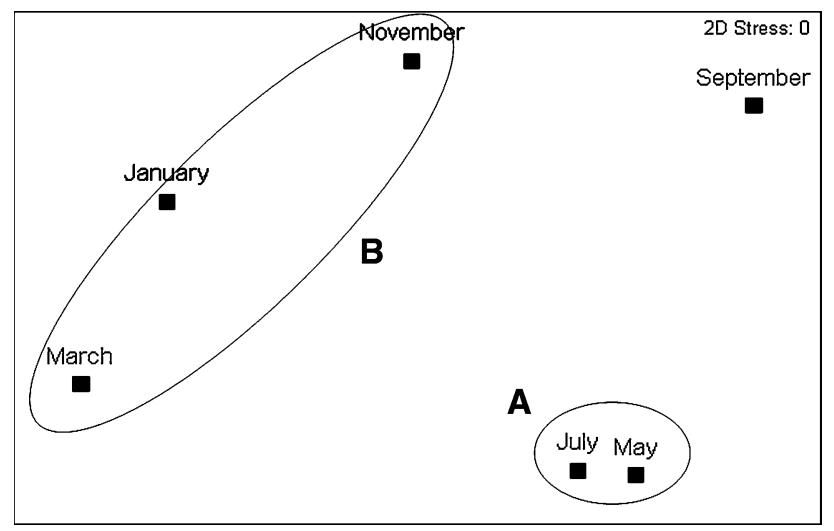

Fig. 5 nMDS ordination of bimonthly samples (centroids) collected at site D27 showing the groups determined by cluster analysis

In the present study, amphipods showed the highest number of species and made the greatest contribution to the total abundance. Amphipod populations also showed great fluctuations through the study period (Fig. 3). These results agree with those of other studies done in similar environments in the northern hemisphere (e.g. Gambi et al. 1992; Dias and Hassal 2005; Quiroz-Vázquez et al. 2005; Ersoy Karaçuha et al. 2009). Dias and Hassal (2005) suggested that amphipods living in seagrasses and feeding on (live or decaying) Zostera eat faster show higher growth rates and also may have larger broods than other groups such as isopods, which might contribute to the numerical dominance and seasonality of their populations.

The life history of the seagrasses can also affect associated organisms via seasonal fluctuations in organic matter supply and alterations of sedimentation rates (Jones et al. 1994; Quiroz-Vazquez et al. 2005; Böstrom et al. 2006; Hasegawa et al. 2008). In particular, Zostera marina shows a clear seasonal dynamics, with elongation of the leaves and rhizomes in spring-summer and spreading of seeds in winter (Hasegawa et al. 2007). This may be reflected in changes of the peracarid faunas, as indicated by the present study. Indeed, some dominant species of the Zostera beds in the O Grove inlet (e.g. Gammarella fucicola, Phtisica marina, Uromunna spp. and Apseudes latreillii, among others) showed great variations in density through seasons (Fig. 4). Guerra-García et al. (2001) reported similar fluctuations of densities for the caprellid, P. marina, influenced by the life cycle of the seaweed, which it is associated with. González et al. (2008) found a correlation between the abundance of $P$. marina and seagrass biomass in Zostera meadows. Likewise, high abundances of $G$. fucicola have been related to detritus accumulation in seagrass meadows right after the decay of the leaves (Lepoint et al. 2006). Furthermore, the increase in seagrass biomass favors the establishment of epiphytic algae, which bloom in August and provide additional food for secondary producers (Hasegawa et al. 2007). This leads to high rates of the secondary production, with grazers such as amphipods of the families Dexaminidae and Amphitoidae as well as most of the isopods reaching their greatest abundances after late summer (Fredette et al. 1990).

The life cycle of Z. marina has been reported to be coupled the breeding and development of certain peracarids. An illustrative example is given by Nakaoka (2002), who reported the tanaidacean Zeuxo not only feeding on $Z$. marina seeds, but also using the spathes for reproduction and nursery. Indeed, we found large numbers of Zeuxo holdichi in summer, just after the anthesis of the seagrass (Fig. 4).

In conclusion, peracarid assemblages in Zostera meadows in the $\mathrm{O}$ Grove inlet are rich and diversified. These findings from the subtidal benthic system of the Galician rias again demonstrate the important ecological role of the seagrasses. As the rias are strongly affected by urbanization and pollution, conservation of these peculiar habitats will be crucial for the preservation of the local biodiversity.

Acknowledgments We gratefully thank the Adaptations of Marine Animals laboratory staff for their invaluable help with sample collection. Constructive comments by two anonymous referees are greatly acknowledged. This work was supported by the Xunta de Galicia (grant number XUGA30101A98).

\section{Appendix}

See Table 5 . 
Table 5 List of peracarid species found during the period of study

\section{Order Amphipoda}

Lysianassa ceratina (Walker, 1889)

Tryphosites longipes (Bate \& Westwood, 1861)

Amphipoda indet.

Ampelisca spp.

Ampelisca brevicornis (A. Costa, 1853)

Ampelisca gibba Sars, 1882

Ampelisca serraticaudata Chevreux, 1888

Ampelisca spinifer Reid, 1951

Ampelisca spinipes Boek, 1861

Ampelisca tenuicornis Liljeborg, 1855

Ampelisca typica (Bate, 1856)

Amphilochus spencebatei (Stebbing, 1876)

Peltocoxa marioni Catta, 1875

Leucothoe incise Robertson, 1892

Leucothoe lilleborgi Boek, 1861

Leucothoe spinicarpa (Abildgaard, 1879)

Stenothoe monoculoides (Montagu, 1815)

Gammaridae indet.

Gammarus spp.

Gammarus crinicornis Stock, 1966

Gammarus insensibilis Stock, 1966

Gammarus tigrinus Sexton, 1939

Gammarella fucicola (Leach, 1814)

Abludomelita gladiosa (Bate, 1862)

Melita dentata (Kroyer, 1842)

Melita herguensis Reid, 1939

Melita palmata (Montagu, 1804)

Urothoe elegans (Bate, 1857)

Urothoe grimaldii Chevreux, 1895

Urothoe pulchela (Costa, 1853)

Perioculodes aequimanus (Kossmann, 1880)

Perioculodes longimanus (Bate \& Westwood, 1868)

Harpinia spp.

Harpinia antennaria Meinert, 1890

Harpinia crenulata (Boeck, 1871)

Harpinia delavallei Chevreux, 1910

Harpinia laevis Sars, 1891

Harpinia pectinata Sars, 1891

Apherusa bispinosa (Bate, 1856)

Apherusa henneguyi Chevreux \& Fage, 1925

Apherusa jurinei (Milne-Edwards, 1830)

Dexamine spinosa (Montagu, 1813)

Ampithoe spp.

Ampithoe gammaroides (Bate, 1856)

Ampithoe helleri Karaman, 1975

Ampithoe neglecta Lincoln, 1976

Ampithoe ramondi Audouin, 1826

Ampithoe rubricata (Montagu, 1808)

Sunamphitoe pelgica (Milne-Edwards, 1830)
Table 5 continued

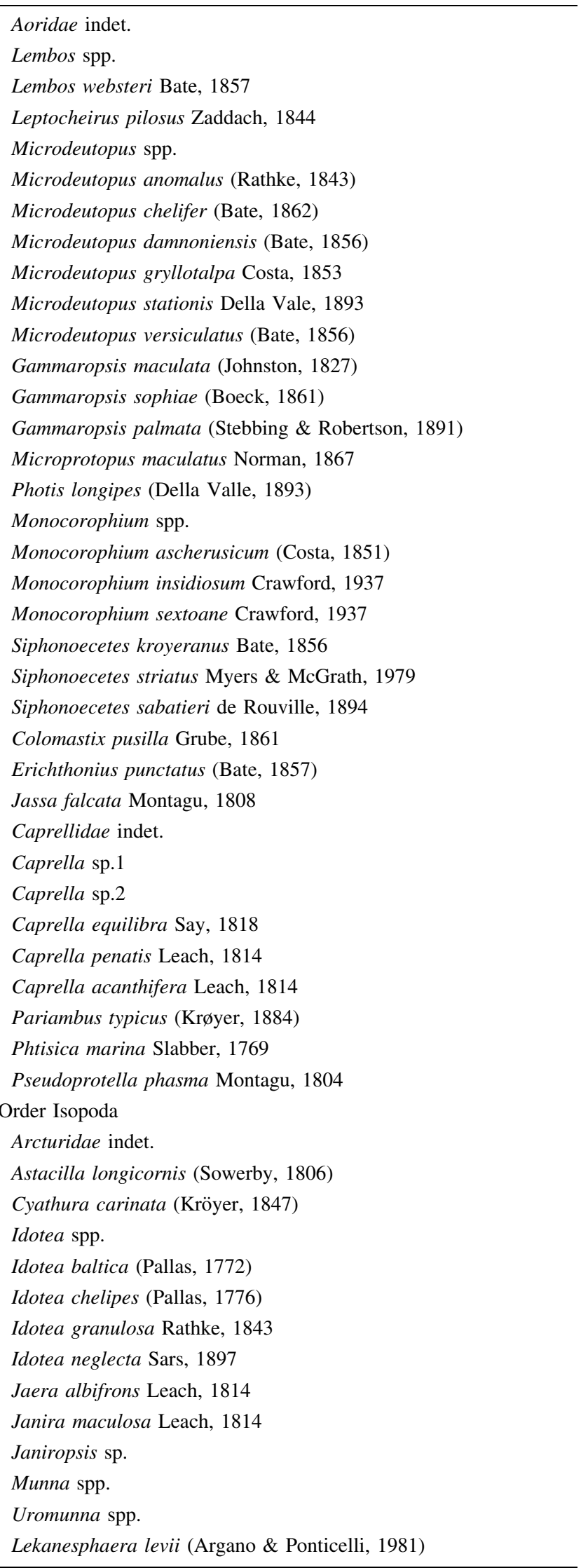


Table 5 continued

\begin{tabular}{l}
\hline Order Cumacea \\
Bodotria pulchella (Sars, 1879) \\
Iphinoe tenella Sars, 1878 \\
Iphinoe trispinosa (Goodsir, 1843) \\
Nannastacidae indet. \\
Nannastacus spp. \\
Cumella spp. \\
Cumella pygmaea Sars, 1865 \\
Pseudocuma longicorne (Bate, 1858) \\
Pseudocuma simile G.O. Sars, 1900 \\
Order Tanaidacea \\
Apseudopsis latreilliii (Milne- Edwards, 1828) \\
Apseudes talpa (Montagu, 1808) \\
Akanthophoreus gracilis (Krøyer, 1842) \\
Leptochelia savignyi (Krøyer, 1842) \\
Tanais dulongii (Audouin, 1826) \\
Zeuxo holdichi Bamber, 1990
\end{tabular}

\section{References}

Blanchet H, de Montaudouin X, Lucas A, Chardy P (2004) Heterogeneity of macrozoobenthic assemblages within a Zostera noltii seagrass bed: diversity, abundance, biomass and structuring factors. Estuar Coast Shelf Sci 61:111-123

Böstrom C, Jackson EL, Simenstad CA (2006) Seagrass landscapes and their effects on associated fauna: a review. Estuar Coast Shelf Sci 68:383-403

Cacabelos E, Gestoso L, Troncoso JS (2008) Macrobenthic fauna of the Ensenada de San Simón (Galicia, Northwestern Spain). J Mar Biol Ass UK 88:237-254

Cartes JE, Elizalde M, Sorbe JC (2001) Contrasting life-histories, secondary production, and trophic structure of Peracarid assemblages of the bathyal suprabenthos from the Bay of Biscay (NE Atlantic) and the Catalan Sea (NW Mediterranean). Deep Sea Res 48:2209-2232

Cartes JE, Papiol V, Palanques A, Guillén J, Demestre M (2007) Dynamics of suprabenthos off the Ebro Delta (Catalan Sea, western Mediterranean): spatial and temporal patterns and relationships with environmental factors. Estuar Coast Shelf Sci 75:501-505

Chintiroglou CC, Antoniadou C, Baxevanis A, Damianidis P, Karalis P, Vafidis D (2004) Peracarida populations of hard substrate assemblages in ports of NW Aegean Sea (Eastern Mediterranean). Helgol Mar Res 58:54-61

Clarke KR, Warwick RM (1994) Changes in marine communities: an approach to statistical analyses and interpretation. Natural Environment Research Council, UK

Cruz S, Gamito S, Marques JC (2003) Spatial distribution of peracarids in the intertidal zone of the Ria Formosa (Portugal). Crustaceana 76:411-431

Cunha MR, Sorbe JC, Moreira MH (1999) Spatial and seasonal changes of brackish peracaridan assemblages and their relation to some environmental variables in two tidal channels of the ria de Aveiro (NW Portugal). Mar Ecol Prog Ser 190:69-87

Currás A, Mora J (1991) Comunidades bentónicas de la Ría del Eo (Galicia-Asturias, NW de España). Cah Biol Mar 32:57-81
Dauvin JC, Alizier S, Vallet C, Rueller T (2009) Does the port 2000 harbour construction have an effect on the Seine estuary suprabenthic community? Estuar Coast Shelf Sci 86:42-50

Dias N, Hassal M (2005) Food, feeding and growth rates of peracarid macro-decomposers in a Ria Formosa salt marsh, southern Portugal. J Exp Mar Biol Ecol 325:84-94

Ersoy Karaçuha M, Siezgín M, Dağli E (2009) Temporal and spatial changes in mixed eelgrass beds, Zostera marina L. and Z. noltii Hornem., at the Sinop peninsula coast (the Southern Black Sea, Turkey). Turkish J Zool 33:375-386

Figueiras FG, Labarta U, Fernández MJ (2002) Coastal upwelling, primary production and mussel growth in the Rias Baixas of Galicia. Hydrobiologia 484:121-131

Fredette TJ, Diaz RJ, Van Montfrans J, Orth RJ (1990) Secondary production within a seagrass bed (Zostera marina and Ruppia maritima) in lower Chesapeake Bay. Estuar Coast 13:431-440

Fredriksen S, Christie H, Sæthre BA (2005) Species richness in macroalgae and macrofauna assemblages on Fucus serratus L. (Phaeophyceae) and Zostera marina L. (Angiospermae) in Skagerrak, Norway. Mar Biol Res 1:2-19

Gambi MC, Lorenti M, Russo GF, Scipione MB, Zupo V (1992) Depth and seasonal distribution of some groups of the vagile fauna of the Posidonia oceanica leaf stratum: structural and trophic analyses. Mar Ecol 13:17-39

Garmendia JM, Sánchez-Mata A, Mora J (1998) Inventario de la macrofauna bentónica de sustratos blandos submareales de la Ría de Ares y Betanzos (NO de la Península Ibérica). Nova Acta Científica Compostelana (Bioloxía) 8:209-231

González AR, Guerra-García JM, Maestre MJ, Ruiz-Tabares A, Espinosa F, Gordillo I, Sánchez-Moyano JE, García-Gómez JE (2008) Community structure of caprellids (Crustacea: Amphipoda: Caprellidae) on seagrasses from southern Spain. Helgol Mar Res 62:189-199

Guerra-García JM, García Gómez JC (2008) Hand corer versus van Veen grab in harbour sediments: efficiency estimation in the study of macrobenthic communities. Zoologia Baetica 19:57-69

Guerra-García JM, García-Gómez JC (2004) Crustacean assemblages and sediment pollution in an exceptional case study: a harbour with two opposing entrances. Crustaceana 77:353-370

Guerra-García JM, Corzo J, García-Asencio I, García-Gómez JC (2001) Seasonal fluctuations of Phtisica marina Slabber (Crustacea: Amphipoda: Caprellidea) in estuarine zone of southwest Spain. Polish Arch Hydrobiol 47:527-532

Guerra-García JM, González-Vila FJ, García-Gómez JC (2003) Aliphatic hydrocarbon pollution and macrobenthic assemblages in Ceuta harbour: a multivariate approach. Mar Ecol Prog Ser 263:127-138

Hasegawa N, Hori M, Mukai H (2007) Seasonal shifts in seagrass bed primary producers in a cold temperate estuary: dynamics of eelgrass Zostera marina and associated epiphytic algae. Aquat Bot 8:337-345

Hasegawa N, Hori M, Mukai H (2008) Seasonal changes in eelgrass functions: current velocity reduction, prevention of sediment resuspension, and control of sediment-water column nutrient flux in relation to eelgrass dynamics. Hydrobiologia 596:387399

Heck JL Jr, Thoman TA (1981) Experiments on predator-prey interactions in vegetated in aquatic habitats. J Exp Mar Biol Ecol 53:125-134

Heck JL Jr, Hays G, Orth RJ (2003) Critical evaluation of the nursery role hypothesis for seagrass meadows. Mar Ecol Prog Ser 253:123-136

Jones CG, Lawton JH, Shachak M (1994) Organisms as ecosystem engineers. Oikos 69:373-386 
Junoy J, Viéitez JM (1988) Crustáceos intermareales de sustrato blando de la ría de Foz (Lugo). Actas III Congreso Ibérico de Entomología:529-540

Lancellotti GA, Trucco RG (1993) Distribution patterns and coexistence of six species of the amphipod genus Hyale. Mar Ecol Prog Ser 93:131-141

Lepoint G, Cox AS, Dauby P, Poulicek M, Gobert S (2006) Food sources of two detritivore amphipods associated with the seagrass Posidonia oceanica leaf litter. Mar Biol Res 2:355-365

Lourido A, Moreira J, Troncoso JS (2008) Assemblages of peracarid crustaceans in subtidal sediments from the Ría de Aldán (Galicia, NW Spain). Helgol Mar Res 62:289-301

Montaudouin X, Sauriau PG (2000) Contribution to a synopsis of marine species richness in Pertuis Charentais Sea with new insights in soft-bottom macrofauna of the Marennes-Oléron Bay. Cah Biol Mar 41:181-222

Moreira J, Troncoso JS (2007) Inventario de la macrofauna bentónica de sedimentos submareales de la Ensenada de Baiona (Galicia, NO Península Ibérica). Nova Acta Científica Compostelana (Bioloxía) 16:101-128

Moreira J, Gestoso L, Troncoso JS (2008a) Diversity and temporal variation of peracarid fauna (Crustacea: Peracarida) in the shallow subtidal of a sandy beach: Playa América (Galicia, NW Spain). Mar Ecol 29(Suppl. 1):12-18

Moreira J, Lourido A, Troncoso JS (2008b) Diversity and distribution of peracarid crustaceans in shallow subtidal soft bottoms at the Ensenada de Baiona (Galicia, N.W. Spain). Crustaceana 81:1069-1089

Nakaoka M (2002) Predation of seagrasses Zostera marina and Zostera caulescens by a tanaid crustacean Zeuxo sp. Aquat Bot 72:99-106

Nelson WG, Cairns KD, Virnstein RW (1982) Seasonal and spatial patterns of seagrass-associated amphipods of the Indian River lagoon, Florida. Bull Mar Sci 32:121-129

Olabarria C, Urgorri V, Troncoso JS (1998) An analysis of the community structure of subtidal and intertidal benthic molluscs of the inlet of Baño (Ria de Ferrol, northwest of Spain). Am Malacol Bull 14:103-120

Orth RJ, Heck KL, Van Montfrans J (1984) Faunal communities in seagrass beds: a review of the influence of plant structure and prey characteristics on predator-prey relationship. Estuar Coast $7: 339-350$

Paganelli D, Sconfietti R, Marchini A (2005) The community of Crustacean Peracarids as indicator of spatial heterogeneity in two Adriatic lagoons: Sacca di Goro (Ferrara) and Lesina lagoon (Foggia). 15th Meeting of the Italian Society of Malacology

Quintas P (2005) Distribución espacial y temporal de los moluscos y anélidos poliquetos asociados a las praderas de Zostera marina L. y Zostera noltii Hornem., en la ensenada de O Grove (Galicia, España). PhD Thesis, University of Vigo, Spain

Quiroz-Vázquez P, Ibarra-Obando SE, Meling-López AE (2005) Composition of the epifaunal community associated with the seagrass Zostera marina in San Quintin Bay, Baja California. Bull South Cal Acad Sci 104:100-112

Riggio S (1996) I Tanaidacei dei mari italiani: quadro delle conoscence. Bolletino del Museo Civico di Storia Naturale di Verona 20:583-698

Sfriso A, Birkenmeyer T, Ghetti PF (2001) Benthic macrofauna changes in areas of venice lagoon populated by seagrasses or seaweeds. Mar Environ Res 52:323-349

Szedlmayer ST, Able KW (1996) Patterns of seasonal availability and habitat use by fishes and decapod crustaceans in a southern New Jersey estuary. Estuar Coast 19:697-709

Talley ST, Dayton PK, Ibarra-Obando S (2000) Tidal flat macrofaunal communities and their associated environments in estuaries of Southern California and Northern Baja California, Mexico. Estuar Coast 23:97-114

Tomasetti P, Persia E, Mercatali I, Vani D, Marusso V, Porrello S (2009) Effects of mariculture on macrobenthic assemblages in a western Mediterranean site. Mar Poll Bull 58:533-541 